\begin{tabular}{ccc}
\hline & International Journal of Engineering \& Technology, $7(3.30)(2018) 320-324$ \\
SPC & Website $:$ www.sciencepubco.com/index.php/IJET \\
Research paper & Technology \\
\hline
\end{tabular}

\title{
Child Delinquency on the Internet
}

\author{
Hendun Abd Rahman Shah ${ }^{1}$, Syahirah Abdul Shukor ${ }^{2}$, Norfadhilah Mohamad Ali ${ }^{3}$, Abidah Abdul Ghafar ${ }^{4}$, Nisar
} Mohammad Ahmad ${ }^{5}$, Nabilah Yusof ${ }^{6}$, Nurul Atira Musa ${ }^{7}$

\author{
${ }^{1}$ Universiti Sains Islam Malaysia \\ ${ }^{2}$ Universiti Sains Islam Malaysia \\ ${ }^{3}$ Universiti Sains Islam Malaysia \\ ${ }^{4}$ Universiti Sains Islam Malaysia \\ ${ }^{5}$ Universiti Sains Islam Malaysia \\ ${ }^{6}$ Universiti Sains Islam Malaysia \\ ${ }^{7}$ Universiti Sains Islam Malaysia \\ *Corresponding author E-mail: hendun@usim.edu.my
}

\begin{abstract}
Recent reported cases and news on children and the Internet reflect the vulnerability of children when they are online, especially with in using the new medium of social networking websites such as Facebook, Instagram, and Twitter. The criminal justice system faces the dilemma when children break the law, as children are considered as minors who are not legally responsible for their actions. In most cases, the society tend to focus on protecting children from neglect, abuse or harms but often overlooked of protecting children who are involved in harming or causing injury to other people or cause damage to property. It is equally important to address the growing concern on children's exposure to usage of the Internet. Thus, the question such as, can the child's wrongs on the Internet be considered as a delinquent act, namely possible wrongful acts conducted by children that would otherwise be an offence if committed by an adult, is explored. The legal status and minimum age of criminal responsibility in Malaysia are also examined. In addition, the Shariah views will be discussed briefly. Then, the paper explores the problems and challenges face by children in using social media websites. Finally, the paper suggests that the government and the community in particular parents and teachers have vital roles to play in ensuring that the policies and rules provide mechanism not only to protect children but also to empower them as a citizen of the country. This may be done by advocating legal awareness and educating the children to be more responsible in their acts online and uphold respect in law, ethics and morality.
\end{abstract}

Keywords: Child delinquency; age of criminal responsibility; Internet's wrong; online crime; social media.

\section{Introduction}

There is a growing concern among the members of society especially parents and teachers on the safety of Internet. Despite having lots of advantages, Internet has been the tool for crime that can be done by anyone even by a child or a young person. Despite that there is no concrete data on the involvement of the Malaysian children on the Internet who might break the existing laws, it is estimated that nearly 20.1 million Internet users in Malaysia are the young generation. They would have owned a smartphone as early as 15 years of age, with the main purpose of accessing Internet. (MCMC, 2016) This growing concern is not limited to developing countries like Malaysia but also include developed countries such as the United Kingdom (UK), United States of America (USA) and Australia.

The challenging part of the Internet is it represents an anonymous user which misrepresentation of age can easily occurred. Thus, it is very difficult to recognize age since there is no specific tool or device that can identify the exact age of the users. Even in the commercial websites where credit card is required for verification, there is a tendency of manipulation of age. There are reports that claim computer games, television and Internet have caused weaknesses in social contact among the children. If real social contact is lacking, how do we expect children to learn a real experience and soft skills in life such as communication skills or even personal attributes in differentiating right and wrong. A German author claimed that the new media have led to 'gradual disappearance of reality' (1). In some circumstances, children may get addicted in using the Internet just like in cases of computer games and the possibility for them to fantasize virtually rather than experiencing the real life. However, mere addiction in using the Internet may not problem until and unless such act encroaches the rights of other person or damage property which are recognized by law. The members of the society are concern on the bad influence of the Internet that may lead an innocent child to become a delinquent child. In worst case scenario, the addiction to the Internet, online games and social media may cause children to commit wrongdoings such as cyber bullying, cyber stalking, cyber grooming, identity fraud, cyber suicide and many other cyber-related offences, without knowing or aware that they are actually committing crime which may, to some extent, make them liable under the local law. As a result of their actions, they might jeopardise their own future.

The criminal justice system has always faced the dilemma of what to do when those who break the law are minors, and thus in many ways not legally responsible for themselves. Most of the time, the society tend to focus on protecting children from neglect, abuse or harms but often overlooked on the protection of children them- 
selves from doing harm. This is equally important and should be addressed in the context of the Internet daily usage. Thus, the question such as, can the child's wrongs on the Internet be considered as a delinquent act, is explored by analysing the meaning of delinquent act. This paper aims to examine the Malaysian legal framework on minimum age of criminal responsibility which may be applicable for wrong doings on the Internet. The Shariah view pertaining to the responsibility of children and arising legal issues relating to children and the Internet in communication and its content are also discussed.

\section{The Concept of Child and the Internet}

Children are known with certain characteristics such as playful, adventurous, vulnerable, fragile and not competent to make important decision in life. Studies made by (2) relate the Internet as a playground for children or teenagers to frolic with their identity. It is essential to understand the concept of child and its relationship with the Internet and how do the characteristics of a child influence their representation and interaction in the cyberspace community. On the other hand, children represent a large number of groups as referred by Franklin. He divides these groups into four different stages: infancy, childhood, adolescence and early adulthood, which pose various needs, rights and responsibilities. Hence, children represent a complex discussion on how far a child can be held responsible for his actions as they present different level of responsibility. We relate responsibility with what is right and wrong in relation to the Internet. Bainham (3) raises the question of children; if they have "rights", do they also have responsibility? Technology has affected our life and, in some circumstances, it puts us in dilemma in differentiating of what is right and wrong especially in teaching our children. Bandalli (4) states that "there is a broad public consensus that the teaching of the difference between right and wrong is failing."

We perceived right and wrong are greatly influenced by the belief, norms and lifestyle of the society and law comes into place to enforce it. If the teaching of right and wrong to our children is failing, should we punish children for their confusion in understanding of what is morally right in the Internet? Our argument is children are more confused with the evolution of the Internet in differentiating what is right and wrong. Great caution should be made in considering the protection to these young offenders- what is the legal response to their best interests? Again, (4) mentions 'right, wrong, naughtiness and serious wrong are complex conceptual issues and the criminal law itself contains a wealth of moral dilemmas.'

There has been extensive research on children on the Internet by media expertise such Professor Sonia Livingstone from London School of Economics (LSE), who examines various issues in relation to children and the Internet. On the other hand, (5) writes about how computers are tools as much as they are a part of our social and psychological lives. Turkle in her book entitled Life on the Screen Technology, in views that 'catalyse changes not only in what we do but in how we think.' In another book, (6) wrote on Alone Together: Why We Expect More from Technology and Less from Each Other, where she assessed the undesirable effects of advancement of technology on human social behavior. Indeed, the development of technology, artificial intelligent as well as Internet of things cannot be avoided from changing the lifestyle of the society. Nonetheless, the human Intelligent must equally be preserved and sustained for not falling into the wave of technology especially those young generations. In today's world, we are witnessing withering moral and ethical aspects when netizens use the Internet irresponsibly. Despite the existing literature stressing on protecting children from being victimised on the Internet, another aspect which should not be forgotten is educating children and young people who are using the Internet with ethics and morality. Teaching of $a d a b$, akhlak and morality can be very challenging in today's world as children are exposed to all sort of information on the Internet and even online from mobile phones.

\section{Defining Child Delinquency}

There is no legal definition of delinquent act within Malaysian legal framework and in most jurisdictions of other countries. Delinquent is defined in Cambridge dictionary as 'a person, usually young, who behaves in a way that is illegal or not acceptable to most people.' It normally referred to as juvenile delinquents. In (7), delinquent is defined as typically of a young person tending to commit crime, particularly minor crime. Hussin (8) uses the term juvenile delinquency to refer to some form of offending acts by youth. The US (9) defines it as an act committed by a juvenile for whom an adult could be prosecuted in a criminal court, but when committed by a juvenile is within the jurisdiction of the juvenile court. The same definition is also used by Bureau of Indian Affairs, Department of Interior and the Canada Juvenile Delinquents Act 1908 (which was later replaced with Young Offenders Act 1984). The 1984 Act was then replaced with the Youth Criminal Justice Act which came into force on 1 April 2003(Canada Department of Justice, 2016). From all above it may be concluded that the offence done by a child shall only be regarded as a delinquent act of a misguided child but not as a criminal.

The delinquent acts of juvenile are divided into two categories; first, acts or omissions which are prohibited and punishable by law under the respective legal systems. Second, acts which are known as status offences, which refer to some behaviours that become offences if it is done by a juvenile person (8). Sanford also highlights that 'the concept of juvenile delinquency entails acts defined by law as acts of delinquency (criminal law violations) and status offences (violation of juvenile laws).' Most literatures refer child delinquency and juvenile delinquency as one group of young offenders who according to the law are defined as children below 18 years old. The Malaysian (9) in its provisions refers the word 'child' including juvenile. However, the United states OJJDP divides young offenders or delinquency into two categories, namely; children below 13 years old and above 13 years old (11). Only delinquent acts done by children below 13 years old are termed as child delinquents. Meanwhile, the wrongful act done by young person above this age is classified as juvenile delinquent (11). They found that it is necessary to classify the young offenders into these two groups, since according to them; the wrongful act done in early age has the tendency to face greater risk of becoming serious and violent juvenile offenders when they are teens (12) Thus, the word delinquent is preferred as against criminal or offender.

This is especially true since children in its nature and age are generally considered incapable of doing crime. They are vulnerable or susceptible to negative influences and outside pressures. With the emergence of social networking websites such as Facebook, Instagram and Twitter, undeniably it brings positive aspects of the Internet to netizens, regardless of age. Flowers commented that many researchers have long associated delinquency with social and economic variables in the life of the delinquent particularly on the broken home theory including marital quality and parental discipline (13). That was the situation during 1980s. The challenges faced by the society today in the era of information technology are not limited to that theory. According to a clinical psychologist, (14) the cause of delinquent behaviour involved various ranks of society including a non-broken home and professional families.

The criminal justice system has always faced the dilemma of what to do when those who break the law are minors, and thus in many ways not legally responsible for themselves. Most of the time, the society tend to focus on protecting children from neglect, abuse or harms but often overlooked on the protection of children themselves from doing harm. This is equally important and should be addressed particularly in the context of the Internet daily usage in order to educate children from doing delinquent acts. The basis of 
criminal responsibility requires three requirements. First, the act committed must be unlawful. Second, this unlawful act is committed with free will. Third, the said act is committed by an adult and sane person who can distinguish between right and wrong (8) Based on this concept, if a crime is committed by children they will not be accountable or made responsible.

\section{Child and Criminal Responsibility}

Thus, analysis of the minimum age of criminal responsibility is important in order to determine the question such as, can the child's wrongs on the Internet make them liable before the law? Article 1 of the United Nations Convention on the Rights of the Child 1989 (UNCRC) defines children as a person 'under the age of 18' years old (Malaysia ratified the UNCRC in 1995). However, UNCRC allows State to determine an earlier age of majority. In addition, the Guidelines for Action on Children in the Criminal Justice System and the UN Guidelines for the Prevention of Juvenile Delinquency (known as the 'Riyadh Guidelines') merely provide some guidelines on the age of criminal responsibility. The Beijing Rules, Rule 2.2(a) of the Standard Minimum Rules for the Administration of Juvenile Justice (UN, 1985) acknowledges that: "A juvenile is a child or young person, who, under the respective legal systems, may be dealt with for an offence in a manner which is different from an adult." This is to ensure a proper administration of juvenile justice system. Again, this rule has not expressly mentioned a standard minimum age of child criminal responsibility to respect the minimum age determined by various states that normally depends on children emotional, mental and intellectual maturity as well as the status of a state economic, political, social and cultural development.

In Malaysia, (9) consolidated 3 former Acts, namely; The Juvenile Courts Act 1947; the Child Protection Act 1999; and the Women and Girls' Protection Act 1973. Its amendment among others, is renaming the Juvenile Court to Court for Children. Section 2 of Child Act that defines 'child' as:

"(a) person under the age of eighteen years; and

(b) In relation to criminal proceedings, means a person who has attained the age of criminal

Responsibility as prescribed in section 82 of the Penal Code [Act 574]."

Various laws and regulation such as Section 2 of (15), Section 10 of (16), Section 10 of the Law Reform (17) and Section 90 of the Penal Code also refer minor or child as a person under the age of 18 years. The Child Act outlines the main structure, processes and procedures for responding to children who commit criminal offences. Pertaining to the issue of criminal responsibility of a child, section 82 of the Malaysian Penal Code clearly protects children under the age of 10 years. Meanwhile, the child who is above 10 and less than 12 years of age will also be exempted from criminal liability if the court found that this particular child 'has insufficient maturity to understand and judge the nature and consequences of his/her conduct.' This is based on the common-law principle of doli incapax. In fact, the Malaysian Penal Code followed English Law in increasing the age of criminal liability of a child in criminal offences from the age of seven years old to ten years old without any definite reason (18) but the presumption of doli incapax remains. It is questionable as whether these tough measures under English law should also be applied to young offender in cases of the Internet wrongs? Whether the wrong committed is grave enough to put into the same level with the offence of murder? There is a gap on literature on how the law responds to child offender who commits wrongs in the Internet and it is submitted that it is a need to identify the types of offences committed by a child in the Internet, whether it should be under civil liability or criminal liability.
In the United Kingdom, presumption of doli incapax under the English Law for 10 to 14 years old children appear to give children greater autonomy and an acknowledgment that they are capable of moral reasoning, while at the same time allowing them to be prosecuted for doing wrong. Furthermore, legislations such as the (19), and Anti-Social Behaviour Act2003 perceive children as capable evil and needing attention of control and youth are being seen as a dangerous group that could threat the harmony of the society. On the other hand, state has responsibility to preserve the order through criminal law and to impose sanction to parents for their children behavior as can be seen in the English Anti-Social Behaviour Act 2003. The Internet is creating a global phenomenon, which does not recognize borders and has transformed the old traditional way of communications and disseminating information. As a result, the law is facing greater challenges of being an instrument of protecting the society from criminal and wrongful act especially, if such acts are committed by anonymous online who happened to be a child.

\section{Criminal Responsibility of Children under the Shari'ah Law}

Generally, under the Shariah law in Malaysia, a child cannot be held responsible for an offence committed if he or she is not baligh, for example in section 51 of the Syariah Criminal Offences (20). The term baligh was interpreted under Section 2(1) of the same Act to mean 'having attained the age of puberty according to Islamic law.' This term may be viewed as rather unclear and uncertain as there is no specific age of criminal liability stated. Nevertheless, in protecting the rights of the child, Shariah law provides general principle that may be use as a guidance for judges to determine a person's criminal responsibility. The rule of liability under the Islamic criminal law categorised a person into various stages of development. The first stage spans from birth until the age of seven which is referred to children who are incapable to understand (sabiy ghair mumayiz). The second stage refers to children with feeble understanding, (sabiyy mumayyiz) which normally denote individuals aged seven to fifteen. Finally, the third stage is referred to a person with maturity and complete understanding (baligh wa Rashid) (21). This is the stage in which a person is said to attain adulthood. Thus, under the Islamic law, the minimum age of criminal responsibility is depending on whether a child has attained the age of puberty as this depicts one capability of complete understanding the consequent for his or her own conduct.

According to (22), generally, the rule of accountability in Islam (taklif) is applicable to all Muslims who has attained puberty. However, the prophet Muhammad SAW absolved three categories of people. This is recorded in the hadith of Sunan Abi Dawud:

"Three (categories of) people are free from responsibility, the insane until he is sane; the sleeping until his wakes up; and the child until him reaching age of maturity." (23)

It is clearly the intention of the Islamic law to exempt children from liability until they attained the age of maturity or puberty (bulugh). According to (24), puberty is a sign of the ending of childhood to a person and the starting of his/her adolescent or adulthood where he/she can be made accountable to all his/her act or omission (taklif). The Islamic schools of thought have different views on the sign of puberty (22). A common criterion of puberty is; autoerotism (ihtilam) for boys and menstruation (haidh) for girls. Physical puberty can be as early as nine years old to fifteen years old in Shafi'e school of law. Meanwhile, to determine whether a person, boy or girl, can be criminally responsible or not, they must reach the latest 15 years according to Shafi'e and Hanbali schools (25-27). Meanwhile, Maliki and Hanafi School of thought except Abu Yusof, who agreed with the opinion of Shafi'e, in view that the age is up to 18 years old (27-28).

It may be concluded that the age of puberty and obligation followed by the age of criminal responsibility of children from 
Quranic perspective is based on a few criteria. First is the child's sexual maturity i.e. the attainment of autoerotism for boys and menstruation level for girls whereas the second criterion is the attainment of growth and intellectual maturity. Mere attainment of puberty or sexual maturity is not sufficient to be accountable for criminal act. The proof of intellectual growth or ability to discern the good and evil (arRushd) must also be shown. The exact age of maturity may be different from one person to another which normally depends on many factors including lifestyle. However, since the Islamic law and practice in Malaysia follows the Shafi'e School, it may be emphasised that 15 years old is the maximum age of maturity for a person either physically or intellectually. Physical maturity will drive him/herself to desires and passions, while the intellectual maturity will encourage him to distinguish between right and wrong and good and evil.

It is noted that, the discussion on the children's exemption of criminal responsibility are referred particularly to the serious crimes fall under the categories of retaliation (Qisas) and Hudud punishment. $(22,28)$ This is because, in other types of crime or civil liabilities, the children or in some cases, parents, can still be held liable and be made responsible (for example to pay $\mathrm{Di}$ yat(compensation)) in order to deter them from doing similar delinquent act in the future. The punishment of this kind may be considered Taazir (punishment other than Hudud) as a mean of educating $\left(T a^{\prime} d i b\right)$ rather than retribution (29). Thus, in cases involving delinquent act of children, the judge may still punish them with a punishment that the judge thinks fit and suitable to them to serve the best interest of the child. The legal rights of child offenders are nuanced, both through the various ways Islamic criminal law is implemented, and the role of the judiciary in expanding the protection of juvenile offenders (30). A well-trained judge who knows to deal with child offender is also crucial in tackling issues of criminal responsibility. The best interests of children should be the paramount agenda in dealing with child offenders. Offering rehabilitation and structured program for children who misbehave while using the Internet is not an easy task. Cyber bullying, cyber stalking and identity theft can lead to disastrous effect if there is no serious attempt made by the society as well as the government in tackling social problems raised on the Internet.

\section{Children and Social Media: Problems and Legal Challenges.}

In discussing the legal challenges of social media in regulating matters related to children, the paper focuses on two aspects: first, victimization of children on the Internet (31) and, second, children who behave anti-social behaviours while using the Internet. Legal issues arising from victimisation of children on the Internet is very wide. However, another aspect which is also creating concern is anti-social behaviours of children especially teenagers on the Internet. (32) claim that the Internet enables anomaly and lawbreaking on forms of cybercrime. In a research conducted by (33) based on web-facilitated and web-enhanced classifications of online deviant behaviour and identity study of offending, gangs, and gang membership to online settings, the problem faced by children and teenagers while surfing the Internet sometimes might not be shared with parents. The study was based on data from the Third Youth Internet Safety Survey (YISS-3), a telephone survey with a nationally representative U.S. sample of 1,560 Internet users, ages 10 to 17 , and their caretakers. Youth's responses to unwanted Internet experiences differ depending on the type of unwanted experiences, whether they are distressed or have other negative reactions caused by the incident and - to some degree other youth characteristics and incident characteristics. Tian $\mathrm{Lu}$ et.al. (34) studied on psychological factors which lead to online intention of delinquency. In another research conducted by (35) in the UK on a group called Troublesome Online Youth Groups
(TOYG), which is based on data collected from subjects in three UK regions. This includes young people who are not in education, employment or training (NEETs). In his research, he explores what are the causes that lead these young people to troll online. Internet trolls become a big concern among the society at large (35). Thus, more legal mechanism is needed to tackle such problem.

Children nowadays are exposed to 'illegal and offensive' content of the Internet. Another major issue is children viewing pornography materials and in worst scenario, children especially teenagers contribute to sexual images on the Internet. Furthermore, with chat application on mobile phone such as WhatsApp, WeChat and Twitter today's young people are reported to misuse the application to the extent that it has contributed to not only Internet addiction but also sex addiction. Besides the positive aspects of the Internet, Internet also becomes a medium to gangsterism which is now online. Navarro, for instance, explores on the relationship of cyber stalking and Internet addiction in a survey conducted among high schools' students in North Carolina, USA (36). Despite increasing number of online crimes such as cyber bullying, cyber stalking and cyber grooming widely reported in the daily newspaper, research which examine specifically on children's delinquency on the Internet and online media is still very limited in Malaysia (37). The lack of law and policy to regulate online crimes and activities may be regarded as main challenges that need quick attention.

\section{Conclusion}

This paper reflects the tensions of regulating legal issues arise from the Internet and children. As pointed by (30), there are still many gaps to be filled in the area of child protection, both in the Muslim and non-Muslim countries. Looking at the frightening development of crime involving children, whether as a victim or a perpetrator, the issues of criminal responsibility of children may be revisited together with the study on the factors contributing to the act of delinquency. Perhaps Islamic law general guideline of determining age of maturity may provide solution to this issue in which criminal liability is measured depends on capacity and maturity of a child. Arguably, it takes a whole village to raise a child. Because prevention is better than cure, hence, children should be guided and supported by family institutions and members of the society in the 'real world' as the strangers in 'cyber world' might jeopardise a child's future due to its wrongdoings on the Internet. Law is seen as a tool to facilitate and accommodate these vulnerable children who are prone to do wrongs not only on the Internet but also in the real world. As wrong doings become rampant especially in social networking websites, it is important to teach our children with soft-skills such as adab, akhlak and morality that need to be disseminated in an online communication in order to build a respectful digital citizenship; a culture of responsibility online and equips children and youth with the ability to judge, navigate and create a range of media content and services, while operating a system of selection, control and protection. All in all, the government and the community in particular parents and teachers have vital roles to play in ensuring that the policies and rules provide mechanism not only to protect children but also to empower them as a citizen of the country which may be done by advocating legal awareness and educating the children to be more responsible in their acts online as well as respect the law and morality.

\section{Acknowledgement}

This is part of the research outcomes of Fundamental Research Grant Scheme (FRGS) entitled 'Developing a Social Media Legal 
Guide for Children' funded by the Ministry of Higher Education. (USIM/FRGS/FSU/32/51015).

\section{References}

[1] Harmut von Henting, as quoted by Crofts, T. 'Doli Incapax: Why Children Deserve Its Protection'. Murdoch University Electronic Journal of Law, available at http://www.murdoch.edu.au/elaw/issues/v10n3/crofts103nf.html.

[2] Sjöberg, U. (1999). The rise of the electronic individual: A study of how young Swedish teenagers use and perceive Internet. Telematics and Informatics, 16(3), 113-133.

[3] Bainham, A. (1998). Changing families and changing conceptsreforming the language of family law. Child \& Fam. LQ, 10, 1 .

[4] Bandalli, S. (1998) 'Abolition of the Presumption of Doli Incapax and the Criminalisation of Children', The Howard Journal, Vol 37, No, 2, May 1998.

[5] Sherry Turkle, (1995), 'Life on the Screen: Identity in the Age of the Internet', Touchstone Edition, New York.

[6] Turkle, S. (2001). Foreword: All MOOs are Educational-the Experience of" Walking through the Self. High wired: On the design, use, and theory of education MOOs.

[7] English Oxford living Dictionary, 2017 see https://en.oxforddictionaries.com.

[8] Nasimah Hussin, (2007), Juvenile Delinquency in Malaysia: Legal Framework and Prospects for Reforms, IIUM Law Journal, 15(2).

[9] United States Office of Juvenile Justice and Delinquency Prevention (OJJDP) see: https://www.ojjdp.gov

[10] Child Act 2001 (Amendment 2016).

[11] Snyder, H. N., Espiritu, R. C., Huizinga, D., Loeber, R., \& Petechuk, D. (2003). Prevalence and development of child delinquency. Child delinquency bulletin series, March 2003.

[12] Loeber, R., Farrington, D. P., \& Petechuk, D. (2003). Child delinquency: Early intervention and prevention. Washington, DC: US Department of Justice, Office of Justice Programs, Office of Juvenile Justice and Delinquency Prevention.

[13] Flowers, R. B. (1986). 'Children and criminality: The child as victim and perpetrator' (Vol. 13). Greenwood Publishing Group.

[14] Azlina@Roszy AG, 'Gajet@Gen $\alpha$,' paper presented at Simposium Penyelidikan dan Meja Bulat, Putrajaya, May, 17, 2017.

[15] Age of Majority Act 1971

[16] Contracts Act 1950

[17] Law Reform (Marriage and Divorce) Act 1976

[18] Majid, M.K. (2001)' Akta Kanak-kanak 2001, Cadangan Pindaan Undang-undang Berkenaan Gejala Sosial' in Siti Zaharah, et, al. (Ed) Siri Undang-undang Mimi Kamariah, Akta Kanak-kanak 2001, Universiti Malaya: Kuala Lumpur, 2002.

[19] Fionda, J. (1999). Crime and Disorder Act 1998: New labour, old hat: Youth justice and the Crime and Disorder Act 1998. Criminal Law Review, (Jan), 36-47.

[20] Syariah Criminal Offences (Federal Territories) Act 1997

[21] Abdul Karim Zaidan (2006) Al Wajiz fi Usul Fiqh. Resalah Publisher: Lebanon.

[22] Wahbah Az-Zuhaili, (2011), 'Bab Al-Ahkam As-Syar'iyyah', Usul Fiqh Al-Islami, Dar Al-Fikr; Beirut.

[23] Al Bayhaqi, 'Kitabul Hudud,' Hadith no 4402, vol.IV, Ma'rifatussunan.

[24] Ibn Abidin, Muhammad Amin ibn Umar, (2000) Hashiyah Radd alMukhtar ala al-Durr al-Mukhtar. V.6. DarrMa'rifah: Beirut.

[25] Ibn Qudamah (1997), Al-Mughni, Dar Alam Al-Kutub; Riyadh

[26] As-Syafie, Muhammad bin Idris. (2001), Al-Umm, Dar-Al Wafaa'; Egypt

[27] An-Nasafi, Abu- Al-Barakat (2011), Kanz Ad-Daqaaiq, Dar AlBashair Al-Islami; Beirut

[28] Anita Abdul Rahim (2009) 'Isu Perundangan Mengenai Hukuman Jenayah Bunuh oleh Kanak-Kanak di Malaysia’, Jurnal UndangUndang dan Masyarakat. (1998)

[29] Al Mawardi (1989) Ahkamul Sultaniyyah, Dar Ibn Qutaibah, Kuwait.

[30] Nisrine Abiad and Farkhanda Zia Mansoor (2010) 'Criminal Law $\&$ the Rights of the Child in Muslim States'. British Institute of International Comparative Law: London.

[31] Utusan Borneo (Sabah). 23 Nov 2016, "Awasi Anak Untuk Elak Jadi Mangsa Pelaku Jenayah Seks'; Sinar 10 October 2016.’Kanakkanak Jadi Hamba Seks Kenalan WeChat"

[32] Stalans, L. J., \& Finn, M. A. (2016). Understanding How the Internet Facilitates Crime and Deviance. 11.
[33] Hsieh, M.L, Mc Shanes, MD and Williams, MF (2016) 'Juveniles in Cyberspace Issues in Enforcement and Parental Control in Understanding Juvenile Justice and Delinquency', McShane, and Cavanaugh, M (eds) USA: Praeger.

[34] Lu, Tian, et, al (2016) 'Psycological factors lead to Delinquency Intention on Online Peer-to-Peer Landing Platform, A Survey Evidence', PACIS 2016 Proceedings.191. Available at http://aisel.aisnet.org/pacis2016/191 Lu Tian,

[35] J. Bishop, (2014) 'Digital teens and the 'Antisocial Network': Prevalance of troublesome Online Youth Groups and Internet trolling in Great Britain' 5(3) International Journal of E-Politics

[36] Navarro, J. N., Marcum, C. D., Higgins, G. E., \& Ricketts, M. L. (2016). Addicted to the Thrill of the Virtual Hunt: Examining the Effects of Internet Addiction on the Cyberstalking Behaviors of Juveniles. Deviant Behavior, 37(8), 893-903.

[37] Utusan Online, 20 October 2011, "Mangsa Dibuli Di Laman Sosial", http://ww1.utusan.com.my/utusan/info.aspy=2011\&amp; dt=1020\& amp;pub=Utusan_Malaysia\&amp;sec=Sains_\%26_Teknologi\&am p;pg=st_01.htm; Harian Metro. 2 July 2016. "WeChat Pilihan Pedofilia Cari Mangsa"

[38] Sanford, J.Fox, (1970) 'Juvenile Justice Reform: A Historical Perspective', 22 Stanford Law Review, 